\title{
The Representation of Literary Motifs in Visual Arts (in Connection with the Magic Belts of Job and His Daughters)
}

\author{
Lyubov Osinkina \\ Oxford University \\ lyubov.osinkina@wolfson.ox.ac.uk
}

To Sebastian Brock

\begin{abstract}
Medieval literature and visual art provide one area of cross-fertilization. The current paper pays special attention to the analysis of the relations between the iconography of Job and its links with oral and written literary tradition. I examine interrelationship between the apocryphal tradition and iconography as illustrated by reference to the 'magic belts' of Job's daughters. I propose that the ability of Job's daughters to understand the language of angels may be linked with their wearing lor(os) which was part of the Byzantine imperial costume and also the angels' attire. In addition, the ribbons commonly found on the heads of angels may be linked with such glossolalia.
\end{abstract}

\section{Keywords}

Apocrypha - Byzantine - Church Slavonic - manuscript illuminations - frescoes Bible

In the Christian tradition the Legend of Job is preserved in several types of sources: biblical, liturgical, exegetic, encyclopaedic and apocryphal. These types are not mutually exclusive. As the present paper shows, medieval literature and visual art provide one area of cross-fertilization. 
In iconography the figure of Job has been represented as an elderly sufferer, a king, an athlete or as Christ's forerunner. Here I investigate the topic of Job's daughters' belts in Byzantine and Slavonic sources and analyse the relations between the iconography and its links with oral and written tradition.

The Testament of Job is an interesting text not only because it deals with heavenly visitors and angelic voices but it also lies at the intersection of Judaeo-Christian encounters. The fact that it exists in Church Slavonic translations and Latin commentaries on the book of Job adds to its interest. The pseudepigraphic Testament of Job survives in Coptic, Byzantine and Slavonic manuscripts. There are several editions of the Greek text ${ }^{1}$ as well as a comprehensive new edition of the Coptic papyrus. ${ }^{2}$

The Church Slavonic manuscript tradition (nine manuscripts dating from fifteenth to eighteenth centuries known at present) has been studied to a lesser degree. Two editions were produced in the nineteenth century. ${ }^{3}$ There is a modern translation into Serbian printed in $2005 \cdot{ }^{4}$ Recently Maria Haralambakis published chapters $1-5$ of the Slavonic text. ${ }^{5}$

One needs to bear in mind the position that the Testament of Job occupies in the Judaeo-Christian sphere. Though some scholars consider Testament of Job a midrash originating within Jewish milieu, others emphasize its Christian overtones. ${ }^{6}$ The attention should be given to the heavenly tongues that daugh-

1 S.P. Brock, Testamentum Iobi (Pseudepigrapha Veteris Testamenti Graece), Leiden, 1967, and The Testament of Job according to the sv Text, ed. R.A. Kraft, Missoula, 1974.

2 Der koptische Kölner Papyruskodex 3221, Teil I: Das Testament des Iob, hrsg. von G. Schenke, mit Beitr. von G.S. Robinson (Sonderreihe Papyrologica Coloniensia, XXXIII), Paderborn, 2009.

3 S. Novaković, “Apokrifna priča o Jovu," Starine, 10 (1878), pp. 157-170, and G. Polívka, "Apokrifna priča o Jovu," Starine, 24 (1891), pp. 135-154. [S. Novaković, Apocryphal story of Job, Antiquites, 1o(1878), pp. 157-170, G. Polívka, Apocryphal story of Job, Antiquites, 24 (1891), pp. 135-154].

4 Т. Јовановић, Апокрифи старозаветни: према српским преписима (Стара српска књижевност у 24 књиге, књига 23.1, Приредио и на савремени језик пренео Томислав Јовановић, Београд, 2005. [Т. Jovanović, Old Testament Apocrypha according to Serbian manuscripts (Old Serbian Literature in 24 volumes, vol. 23.1), Prepared and translated into the modern language by Tomislav Jovanović, Belgrade, 2005].

5 M. Haralambakis, The Testament of Job: Text, Narrative and Reception, Bloomsbury, 2012, pp. 186-191.

6 Kohler, as seen from the title of his publication, talks about Essenes, cf. K. Kohler, "The Testament of Job, an Essene Midrash on the Book of Job," in: Semitic Studies in Memory of Rev. Dr. Alexander Kohut, ed. G.A. Kohut, Berlin, 1897, pp. 264-338. Marc Philonenko is in favour of the Therapeutae, see M. Philonenko "Le Testament de Job et les Therapeutes," Semitica, 8 (1958), pp. 41-58. Russell Spittler talks about the further reworking of the apocryphal text by Montanists in the 2nd century CE, cf. R.P. Spittler, "Testament of Job," in: The Old Testament Pseudepigrapha, ed. J.H. Charlesworth, vol. 1, Garden Ciry, NY, 1983, pp. 829-868, here p. 834. 
ters of Job are able to speak and understand in the final chapters of the book and its Church Slavonic terminology.

By referring to the 'magic belts' of Job's daughters and examining manuscript illuminations, frescoes, icons and mosaics I show the interrelationship existing between the apocryphal tradition and iconography. Jennifer Zilm ${ }^{7}$ wrote about the multicoloured garments of Job's daughters relating them to the Jewish high priests' sashes.

Chapters 46-53 Testamentum Iobi some scholars consider to be a late addition. Apart from the Coptic papyrus, the existing copies of the text originate from the medieval period. Therefore with insight the story of the daughters' inheritance should be viewed not only from a Jewish but also from a Christian perspective. I propose that the ability of Job's daughters to understand the language of angels may be linked with the wearing of a scarf resembling lor (loros) which was part of the Byzantine imperial costume and also the angels' attire. Job in answer to daughters' question about the usefulness of the cords says:

Put these as girdles around you in order that all the days of your life they may encircle you and endow you with everything good. Not only have you here sufficient to live on, but these bring you into a better world to live in, in the heavens. Or do you not know my children, the value of these things here? Hear then! When the Lord had deemed me worthy to have compassion on me and to take off my body the plagues and the worms, He called me and handed to me these three strings. And He said to me: 'Rise and gird up thy loins like a man I will demand of thee and declare thou unto me'. And I took them and girt them around my loins, and immediately did the worms leave my body, and likewise did the plagues, and my whole body took new strength through the Lord, and thus I passed on, as though I had never suffered. But also in my heart I forgot the pains. Then spoke the Lord unto me in His great power and showed to me all that was and will be.

In the Greek MSs of the apocryphal Testament of Job in place of 46:7 there



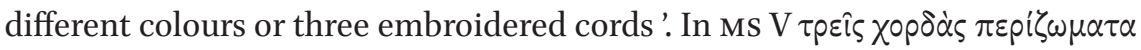
- 'Three cords, belts', so in the sentence there are two direct objects in the

Compare this with the well known replica of M James, one of the first publishers of the Greek text: "If we think of [the author] as a Jew by birth, a Christian by faith, and as living in Egypt in the second and third century, we shall not, I believe, be far wrong" (M.R. James, Apocrypha Anecdota II (Texts and Studies, v), Cambridge, 1897, pp. lxxii-cii, 103-137).

7 J. Zilm, "Multi-Coloured like Woven Works: Gender, Rirual Clothing and Praying with the Angels in the Dead Sea Scrolls and the Testament of Job," in: Prayer and Poetry in the Dead Sea Scrolls and Related Literature: Essays in Honor of Eileen Schuller on the Occasion of her 65th Birthday, eds. J. Penner, K.M. Penner, and C. Wassen, Leiden, 2012, pp. 437-451. 
absence of attributive adjective. In MS S the reading is $\tau \dot{\alpha} \varsigma \pi \circ x^{\prime} \lambda \alpha \varsigma$ - various shades.

It seems that these words are not generally the accepted ones for defining

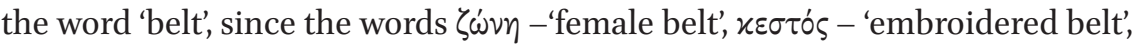

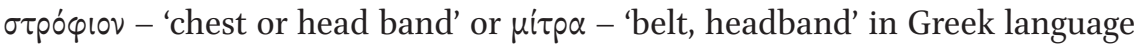
were used instead. The Greek word $\pi 0 เ x$ ' $\lambda$ ○ s has the meaning of not only 'multicoloured' but also 'embroidered'. 8 Therefore both meanings could be characteristic of loros embroidered chest belt richly decorated with multi-coloured stones. The fact that in chapter 46:5 Testament ofJob three caskets with gold are stated, could serve as indirect evidence in favour of richly decorated belts, similar to details of the byzantine imperial attire.

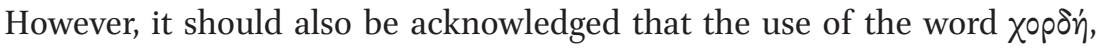
which means the 'string,' 'chord', in any case something narrow, made from animal hide poses an obstacle to such interpretation. The noun $\chi 0$ o $\delta$, meaning 'string' more likely is associated with the music of celestial spheres, since Job's daughters upon receiving magic belts/strings begin to play string instru-

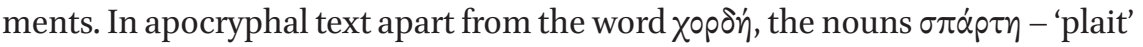
and $\pi \varepsilon p i \zeta \omega \sigma \iota \varsigma$ - 'belt' were used as synonyms to the latter. Therefore the choice of these words appears to be even more mysterious and unusual in denoting the magic belts as an inheritance from Job.

Literary parallels to the episode in Testament of Job could be found in the Old Testament apocryphon Apocalypse of Zephaniah, ${ }^{9}$ in which the angel by the name Eremiel appears to the hero. In the text we have only the description of his shining face and his attire with criss-cross belt on his chest. Further on in the Apocalypse (8:14) it is described how Zephaniah by putting on the angels' attire (however, the mention of a belt in this passage is omitted) finds the capability to understand angelic language. It is obvious that the acquired ability of understanding the angels' tongue depends on wearing the angel's attire in general and the criss-cross chest belt in particular. Thus the idea about the connection of wearing chest belts with the skill to talk in angelic language receives its plausibility from the Testament of Job. This type of girding can be seen on the Byzantine mosaic from the Cappella Palatina, XII c. Angel with loros or mosaic from the Church of Dormition, Nicea, circa 843 with Heavenly Forces $\triangle$ YNAMIC and APXE. We find similar attire of Job's daughters in the miniature from the Coptic MS VIII c. (I.B.18, f. 4v), Naples, National Library portraying Job, the righteous, with his daughters.

8 For the study of girdles, sashes and belts see H. Omerzu, "Women, Magic and Angels: On the Emancipation of Job's Daughters in the Apocryphal Testament of Job," in: Bodies in Question: Gender, Religion, Text, Aldershot, 2005, pp. 85-103.

9 J.H. Charlesworth, The Old Testament Pseudepigrapha, vol. 1, Garden City, NY, 1983, pp. 497-515. 
It is difficult to say what is primary in this case: iconographic symbolism of precious belts or their literary description. To answer the following question we need further investigation in the field of iconography as well as literature. It seems that here they influence each other. It is possible to say that there was a convergence of art and literature during this period. All said this prompts us to view the episode of the magic belts of Job's daughters with special attention. It is reasonable to ask the question did the literary description of belts goe back to the iconographic details of the angels' attire and byzantine imperial costume or vice versa? What are we dealing with in this case? Does it mean that I am choosing an easier way, preferring to talk about interaction between literary text and iconography?

In addition to a scarf resembling loros, ribbons which are commonly found on the heads of angels may also be linked with such glossolalia. Michael Psellos mentions angels' headbands in his treatise on iconography of angels: $\dot{\eta} \delta \dot{\varepsilon} \lambda \varepsilon \pi \tau \dot{\eta}$

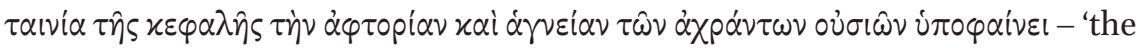
thin braid around their head shows the purity and chastity of their undefiled nature. ${ }^{10}$ These ribbons can be seen on many images (to give but one example is the Angel's head, of Trinity image. Fresco from the church of Transfiguration of Christ on Il'ina street, by Theophanes the Greek, Novgorod.). They originated from the ancient diadems similar to the ones worn by the rulers of Ptolemaic dynasty on contemporary coins. See in the illustration below of Emperor Arcadius with a diadem (Roman gold solidus circa 402 - 408 AD). From images on various coins it can be noted that gradually the initial white ribbon tied around the head of potentates was replaced by a more fanciful one decorated with precious stones.

It would be tempting to connect the ability of Job's daughters of mastering the angelic language with the head bandages, ribbons of angels, though I must admit, that right now there are no grounds for this. In the Old Russian text the head bandages bear the name 'слухи' - (hearings, sounds) or 'тороки' - (ribbons, threads). In medieval iconography 'слухи' act as an instrument with the help of which angels could hear and obey the word of God. We can view 'слухи' like the peculiar [sui generis] mobile phones with the help of which angels could listen and obey God's instructions. Cf. the text from the Chudov chronograph:

10 Cf. K. Snipes, "An unedited treatise of Michael Psellos on the iconography of angels and on the religious festivals celebrated on each day of the week," Gonimos. Neoplatonic and Byzantine Studies Presented to Leenderst G. Westerlink at 75, ed. J. Duffy and J. Peradotto, Buffalo NY, 1988, pp. 189-205, here p. 200. 
O ангелех, иже имут над ушима тороцы. Ангели имут над ушима тороцы, еже есть покоище святого духа, иже и действо имут. А иже над челом белость, то есть слухи. Егда приидет повеление от господа, тогда слух вострепещет у архангела и абие зрит в зерцало, иже имать в руце, и обретает повеленное ему от господа в зерцале написано, яко же кто пишет на воде перстом. Яко бы тому единому разумети точию. Сея ради вины имут ангели слухи и зерцала. ${ }^{11}$

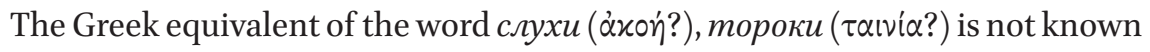
to me. ${ }^{12}$ In the study of angels by Glenn Peers there is no mention of angelic bands. ${ }^{13}$ But I found confirmation of the existence in Byzantine iconography of similar ribbons - 'слухов' in the illuminations decorating the mediaval ms of Psalter from Winchester. On one of the folios the artist painted angels and apparently misinterpreted the fluttering ribbons of headband mistaking them for hair curls. ${ }^{14}$

In conclusion I suggest that the reflection of the literary plot on Job's girdles in visual arts can be viewed as an example of intersemiotic translation with the hope that further research will help to find the corresponding Greek term for 'слухи' and shed light on the magical ribbons of Job's daughters.

[М. Сперанский], Библиографические материалы А.Н. Попова. г) Хронографы Чудова монастыря [M. Speranskij, ed.], Bibliographical Materials (collected by) A.N. Popov. c) Chronographies of the Chudov Monastery], Чтения в Императорском Обществе истории и древностей российских при Московском университете [The Lectures in the Imperial Society of History and Antiquities of Russia at the University of Moscow] 3 (150) (1889), Nr XVIII, 1-72, here p. 50.

Avvakum mentioned 'тороки слухи' in his autobiography: “бело у ушей-тех их" (А.Н. Робинсон, Жизнеописания Аввакума и Епифания: Исследование и тексты, Moscow, 1963, p. 177. [A.N. Robinson, Lives of Avvacum and Epiphany: Analysis and texts, Moscow, 1963, p. 177].

13 Cf. G. Peers, Subtle Bodies: Representing Angels in Byzantium, Berkeley, 2001.

14 Cf. H.A. Klein, "The so-called Byzantine Diptych in the Winchester Psalter, British Library, MS Cotton Nero C. IV," Gesta, 37.1 (1998), pp. 26-43. 